\title{
Efficacy and Safety of Exenatide versus Insulin in Type 2 Diabetes Mellitus: Systematic Review and Meta-Analysis
}

\author{
Bao-Ju Chen ${ }^{1}$ \\ Ju Chuko ${ }^{1}$ \\ Chi-Hua Tung ${ }^{2}$ \\ "Kuang-Yu Hu ${ }^{2}$

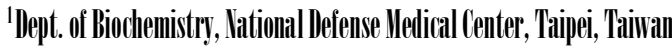

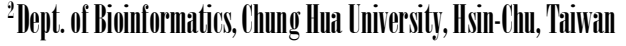

\begin{abstract}
Exenatide is one of a new class of medications (incretin mimetics) for the treatment of type 2 diabetes mellitus and was approved in April 2005 by the U.S. Food and Drug Administration. We undertook a systematic review and meta-analysis of exenatide therapy compared to both placebo and insulin therapy in terms of main efficacy parameters and safety. We searched PubMed for randomized controlled clinical studies of type 2 diabetes mellitus of at least 12 weeks' duration published from June 2003 to July 2010. Exenatide reduced the mean differences of HbAlc comparing with both placebo $(-0.88 \%$ [95\% CI -0.98 to -0.79$])$ and insulin ( $0.05 \%$ [95\% CI -0.11 to 0.21$])$. And, mean differences of body weight were reduced for exenatide comparing with both placebo $(-1.18 \mathrm{~kg}$ [95\% CI -1.44 to -0.93$])$ and insulin $(-5.42 \mathrm{~kg}$ [95\% CI -5.89 to -4.95]). Exenatide has beneficial effects on glycemic control and is relatively safe in terms of the adverse events studied. The glycemic control effects of exenatide and insulin are similar, but the body weight reduction effects of exenatide are greater. This indicates that exenatide provides another choice for type 2 DM patients who have weight control problems.

Keywords: Exenatide, diabetes mellitus, meta-analysis, evidence based medicine

JEL : IIO
\end{abstract}

Diabetes mellitus (DM) is one of the most common chronic diseases and has an increasing incidence worldwide. Recent estimates suggest that there were 171 million people throughout the world living with diabetes in the year 2000, and this number is projected to increase to 366 million by 2030 (Wild et al., 2004). Moreover, most of these people were or will be diagnosed with type 2 DM. This chronic and progressive disease has no established cure, but there are well-established treatments for it which can delay or prevent entirely the formerly inevitable consequences of the condition. Successful management of type 2 DM requires strict control of glycemia as well as other risk factors to prevent disease complications (UK Prospective Diabetes Study Group, 1998).

Body weight management is one of the major issues of type 2 DM patients. Successful weight management not only affects glycemic control, but also improves overall health (Seagle et al., 2009). All the oral anti-diabetic medications (sulfonylurea (SU), $\alpha$-glucosidase inhibitor, thiazolidinediones, 
International Journal of Management, Economics and Social Sciences

etc) may cause weight gain, except for metformin (Bjorkhem-Bergman, Asplund and Lindh, 2010; Nathan et al., 2009a). Insulin therapy is commonly used to help type 2 DM patients achieve adequate glycemic control, especially for cases in which the control provided by an oral medication is insufficient (Nathan et al., 2009b). Nevertheless, insulin therapy results in weight gain (Swinnen et al., 2010). This makes body weight management difficult for type 2 DM patients.

Exenatide (Byetta $\AA^{8}$, Amylin Pharmaceuticals) is one of a new class of anti-diabetic medications called incretin mimetics. This injectable prescription medicine is currently available as an adjunctive therapy in many countries, including the United States and the member states of the European Union, for type $2 \mathrm{DM}$ patients who are taking MET, SU, or a combination of MET and SU, but have not achieved adequate glycemic control. Exenatide imitates the actions of naturally occurring GLP-1 (glucagon-like peptide 1), which binds to the pancreatic GLP-1 receptor and improves glucose homeostasis. It stimulates insulin release in a glucose-dependent manner, improves first-phase insulin release, induces a delay of gastric emptying, decreases food intake, and ultimately results in body weight reduction (Verspohl, 2009).

Both exenatide and insulin are injectable and can be prescribed for patients with inadequate glycemic control on oral medications (Nathan et al., 2009b). Some reviews have examined the efficacy of exenatide but only in comparison to placebo (Amori, Lau and Pittas, 2007; Norris et al., 2009). In the present study, we provide an update on those reviews by including the relevant randomized controlled trials published up through 2010 in our meta-analysis. In addition, the aim was to compare exenatide not only to placebo but also to insulin therapy in terms of efficacy and safety in type 2 diabetes, especially with regard to body weight changes.

\section{METHODOLOGY}

\section{-Data Sources and Search}

We conducted a search of PubMed for clinical trials of exenatide for type 2 diabetes published from June 2003 to July 2010 using the following search terms: "exenatide" [Substance Name] and "Diabetes Mellitus, Type 2" [MeSH] and "humans" [MeSH Terms] and "Clinical Trial" [ptyp].

\section{-Study Selection}

Publications were included in the meta-analysis if they (1) were prospective, randomized, and controlled with placebo or insulin therapy, (2) were at least 12 weeks in duration, (3) included nonpregnant adults with type 2 diabetes mellitus, (4) examined the efficacy of exenatide alone or in combination with other oral agents, and (5) had reported hemoglobin $\mathrm{A} 1 \mathrm{c}(\mathrm{HbA1C})$ outcomes in a manner that allowed data analysis. 


\section{Chen et al.}

We excluded studies of less than 12 weeks' duration because such studies would not give an adequate assessment of the change in glycemic efficacy, as HbA1c concentrations reflect glycemic control during the previous 3 months. We also excluded publications that assessed exenatide in terms of pharmacokinetics or economics.

\section{-Data Extraction and Quality Assessment}

For the included studies, we extracted information about the following variables: sample size, study duration, participants' baseline characteristics, drug interventions, study design, and dropout rate (see Table 1-Appendix-I). For glycemic efficacy, we extracted the mean change in the HbA1C and fasting plasma glucose (FPG) levels from baseline to study endpoint, as well as the percentage of participants achieving $\mathrm{HbA} 1 \mathrm{C}$ concentrations of less than 7 percent. Other variables extracted were the mean change in body weight and the occurrence of reported adverse effects.

\section{-Data Synthesis and Analysis}

The primary outcome was the mean change in $\mathrm{HbA} 1 \mathrm{C}$ concentrations from baseline to study endpoint. The secondary outcomes were the mean change from baseline to study endpoint in FPG levels, the proportion of participants reaching $\mathrm{HbA} 1 \mathrm{C}$ concentrations of less than 7 percent, body weight, and the occurrence of all reported adverse events. For continuous variables (HbA1c concentration, FPG level, and body weight), mean differences and 95 percent confidence intervals (Cls) were obtained using the fixed effect inverse variance (IV) method. For dichotomous variables (percentages achieving HbA1c concentrations of less than 7 percent and percentages with adverse events), the odds ratios (OR) and 95\% Cls were calculated by the fixed effect Mantel-Haenszelor $(\mathrm{M}-\mathrm{H})$ method. The 12 statistic was used to evaluate statistical heterogeneity in each meta-analysis. This describes the percentage of the variability in effect estimates that is due to heterogeneity rather than sampling error. An 12 value greater than $50 \%$ was considered indicative of at least moderate heterogeneity (Higgins et al., 2003). Statistical analyses were performed using Review Manager (RevMan) version 5.0.22 for Windows (The Nordic Cochrane Centre, Copenhagen).

\section{RESULTS}

\section{Search Results and Study Characteristics}

The search results are summarized in Figure 1. A total of 57 publications were identified in our PubMed search. After critical evaluation, it was found that 11 publications met all the inclusion criteria for the meta-analysis. The characteristics of the 11 included trials are summarized in Table 1. Six publications evaluated exenatide with a dosage of $10 \mu \mathrm{g}$ BID in combination with metformin, sulfonyl- 
urea, combined metformin/sulfonylurea, or combined thiazolidinedione/metformin therapy in randomized placebo-controlled trials (Buse et al., 2004; DeFronzo et al., 2005; Gao et al., 2009; Kendall et al., 2005; Moretto et al., 2008; Zinman et al., 2007). Four of them also had a parallel group of exenatide with a dosage of $5 \mu \mathrm{g}$ BID. There was only one trial for LAR (long-acting release) exenatide (Kim et al., 2007). Four publications compared the efficacy of exenatide with open-label subcutaneous insulin (glargine and biphasic aspart) (Bergenstal et al., 2009; Davis et al., 2007; Heine et al., 2005; Nauck et al., 2007).

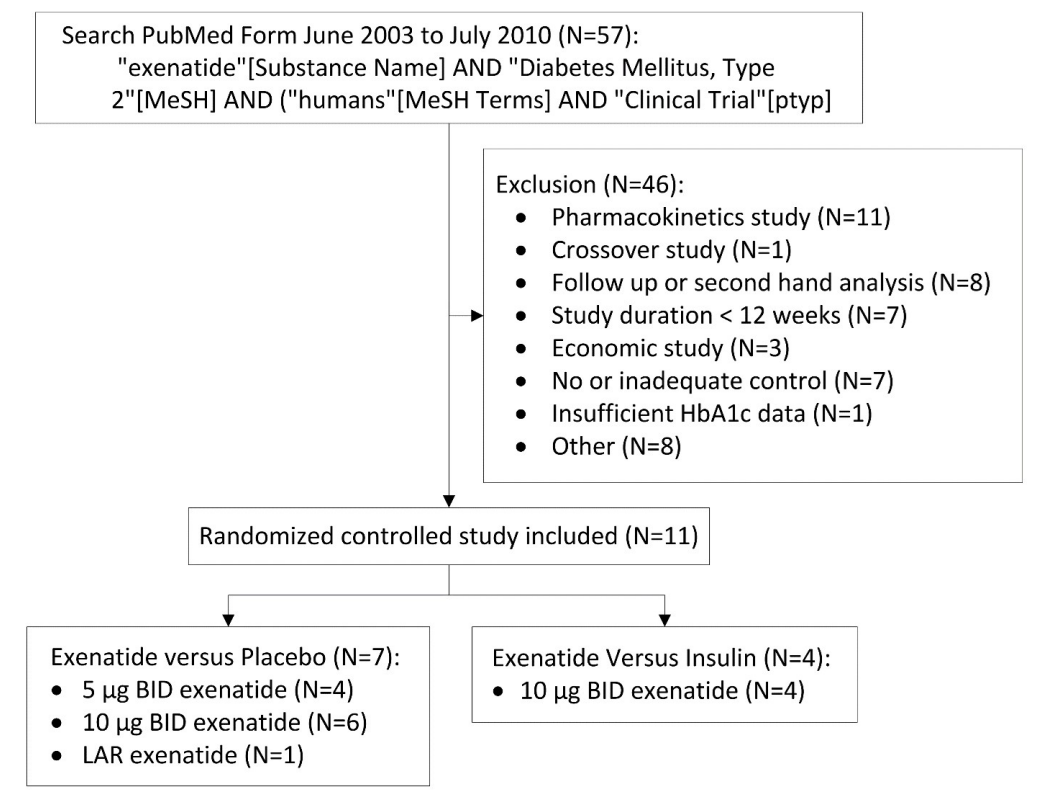

Figure 1. Study Design

\section{Methodological Quality}

Six of the 11 publications (55\%) were triple-blind or double-blind placebo-controlled trials, and the other 5 publications $(45 \%)$ were open-label. The range of dropout rates from intervention prior to the conclusion of the study was $0-31$ percent, and only $3(27 \%)$ studies had dropout rates over 20 percent (Table 1).

\section{Glycemic Outcomes: Hemoglobin A1c (HbA1c)}

Combining data from the studies comparing exenatide with placebo showed statistically significant differences in HbA1c concentration declines from baseline favoring exenatide therapy in doses of both $5 \mu \mathrm{g}$ BID (mean difference $-0.63 \%$ [95\% $\mathrm{Cl}-0.76$ to -0.50]; see Figure 2a-Appendix-II) and $10 \mu \mathrm{g}$ 


\section{Chen et al.}

BID (mean difference $-0.88 \%$ [ $95 \% \mathrm{Cl}-0.98$ to -0.79$]$ ). There was no statistically significant difference in HbA1c concentration declines between exenatide and insulin (mean difference 0.05 percent [95\% Cl -0.11 to 0.21$]$ ). There was only one trial for LAR exenatide, but the two dosages of LAR exenatide both reduced HbA1c concentrations compared with the same dosages of placebo (mean difference $-1.8 \%$ [ $95 \% \mathrm{Cl}-2.63$ to -0.97 ] $(0.8 \mathrm{mg})$ and $-2.10 \%[95 \% \mathrm{Cl}-2.93 \%$ to $1.27 \%$ ] $(2.0$ mg); data not shown) (Kim et al., 2007).

Patients receiving exenatide were more likely to reach the goal of an $\mathrm{HbA1c}$ concentration of less than $7 \%$ than those receiving placebo (odds ratio $3.54[95 \% \mathrm{Cl} 2.49$ to 5.05$]$ (5 $\mu \mathrm{g} \mathrm{BID)}$ ) and 5.15 , [95\% Cl, 4.03 to 6.59] (10 $\mu \mathrm{g} \mathrm{BID);} \mathrm{see} \mathrm{Figure} \mathrm{2b-Appendix-II).} \mathrm{However,} \mathrm{when} \mathrm{exenatide} \mathrm{was}$ compared with insulin, the odds ratio of achieving that $\mathrm{HbA} 1 \mathrm{c}$ concentration goal favored insulin $(0.99$ [95\% Cl 0.79 to 1.25$]$ ).

\section{Glycemic Outcomes: Fasting Plasma Glucose (FPG)}

The reductions in fasting plasma glucose levels favored exenatide over placebo (weighted mean difference $-0.99 \mathrm{mmol} / \mathrm{L}[95 \% \mathrm{Cl}-1.31$ to -0.68$]$ (5 $\mu \mathrm{g} \mathrm{BID}$ ); $-1.25 \mathrm{mmole} / \mathrm{L}[95 \% \mathrm{Cl}-1.49$ to 1.01] (10 $\mu \mathrm{g} \mathrm{BID);} \mathrm{see} \mathrm{Figure} \mathrm{3-Appendix-III).} \mathrm{Comparing} \mathrm{exenatide} \mathrm{with} \mathrm{insulin,} \mathrm{the} \mathrm{declines} \mathrm{in}$ fasting plasma glucose levels favored insulin (weighted mean difference $2.24 \mathrm{mmole} / \mathrm{L}[95 \% \mathrm{Cl} 2.16$ to 2.32$])$.

\section{Nonglycemic Outcomes: Weight}

The body weight reductions from baseline were significantly in favor of exenatide over placebo (weighted mean difference $-0.85 \mathrm{~kg}[95 \% \mathrm{Cl}-1.22$ to -0.47$](5 \mu \mathrm{g} \mathrm{BID}) ;-1.18 \mathrm{~kg}[95 \% \mathrm{Cl}-1.44$ to -0.93] (10 $\mu \mathrm{g}$ BID); see Figure 4-Appendix-IV). Compared with insulin, the declines in body weight were significantly greater for exenatide (weighted mean difference $-5.42 \mathrm{~kg}[95 \% \mathrm{Cl}-5.89$ to -4.95$]$ ).

\section{Nonglycemic Outcomes: Adverse Events}

Hypoglycemia was commonly reported in the analyzed exenatide trials. Compared with placebo, the odds ratios for hypoglycemia with exenatide treatment were greater than 1 (1.92 [95\% $\mathrm{Cl} 1.28$ to 2.88] (5 $\mu \mathrm{g} \mathrm{BID);} 3.17$ [95\% Cl 2.24 to 4.48] (10 $\mu \mathrm{g}$ BID); see Table 2-Appendix-V). There was only one trial that compared exenatide with insulin in this regard, and it showed that, in comparison, the odds ratio for hypoglycemia with exenatide was smaller than $1(0.63$ [95\% $\mathrm{Cl} 0.41$ to 0.97$])$. Gastrointestinal-related adverse events like nausea, vomiting, and diarrhea all had odds ratios greater than 1 for $10 \mu \mathrm{g} \mathrm{BID}$ exenatide compared with both placebo (5.25 [95\% Cl 4.07 to 6.77] , 6.71 [95\% Cl 4.13 to 10.89$], 5.36$ [ $95 \% \mathrm{Cl} 3.18$ to 9.04 ], respectively) and insulin ( 20.89 [95\% $\mathrm{Cl} 13.04$ to 
33.49 ], 5.36 [ $95 \% \mathrm{Cl} 3.18$ to 9.04 ], 3.80 [95\% Cl 2.03 to 7.10 ], respectively).

\section{DISCUSSION}

Compared to placebo, both dosages of exenatide (5 $\mu \mathrm{g}$ BID and $10 \mu \mathrm{g}$ BID) had beneficial effects on glycemic control, including in terms of $\mathrm{HbA1c}$ concentration reductions, the number of patients achieving the goal of an $\mathrm{HbA1c}$ concentration of less than 7 percent, and fasting plasma glucose levels. Moreover, exenatide was shown to be relatively safe in regard to adverse events and the ability to reduce body weight. When compared to insulin, exenatide had a similar effect on glycemic control, but exenatide was associated with significantly greater reductions in body weight.

In addition to glycemic control, body weight reduction is the most obvious effect of exenatide. Insulin therapy regulates the absorption of glucose by diabetes patients, but it also has the commonly occurring side effect of weight gain. Insulin injections directly control blood sugar levels by inducing glucose to be stored in cells and reducing glucose levels in urine. The glucose taken in by cells will be used as an energy source or stored as fat; therefore, the overall utilization of fat will be decreased. As such, by continuing to eat as before, patients will likely gain weight after they start taking insulin. Relatedly, this study found that the most significant advantage of exenatide in comparison to insulin is the reduction in body weight. Furthermore, body weight reduction also helps to lower blood glucose, blood pressure, and cholesterol levels (Feldstein et al., 2008). Finally, it can improve the overall health of patients with diabetes.

Hypoglycemia is one of the common adverse effects of exenatide treatment in comparison to placebo therapy. However, we found that hypoglycemia was less commonly induced by exenatide than by insulin injection. Exenatide stimulates insulin secretion in response to food intake, and the result is the release of higher, more moderate amounts of insulin that help reduce the increase of blood sugar caused by eating meals. Once blood sugar levels fall nearer to normal values, the pancreatic response to produce insulin is decreased. Meanwhile, although injectable insulin is effective in lowering blood sugar, it can also cause blood sugar to drop too low, resulting in the dangerous situation of hypoglycemia (Heine et al., 2005). The use of exenatide can thus reduce the risk of hypoglycemia from insulin therapy for type 2 diabetes patients.

\section{CONCLUSION}

In this meta-analysis, gastrointestinal tract symptoms, including nausea, vomiting, and diarrhea, were the other common adverse effects. There were two warnings from the U.S. Food and Drug Administration (FDA) in post-marketing reports for exenatide, and those warnings were in regard to 


\section{Chen et al.}

acute pancreatitis and renal failure (U.S. Food and Drug Administration, 2007, 2009). Relatedly, the serious effects of renal failure may be associated with the aforementioned common adverse effects, such as vomiting and nausea (Weise et al., 2009). This indicates that a patient who has kidney dysfunction or a history of pancreatic disease, as well as serious adverse effects of vomiting and nausea, should be more careful when using exenatide.

The effects of exenatide on blood glucose control and body weight lowering were obvious. Since exenatide has a glycemic control effect similar to that of insulin and also has the ability to lower body weight, for type 2 DM patients who cannot achieve adequate glycemic control from oral anti-diabetic medications, especially those who have body weight problems, exenatide offers another choice of

\section{REFERENCES}

Amori, R. E., Lau, J. \& Pittas, A. G. (2007). Efficacy and safety of incretin therapy in type 2 diabetes: systematic review and meta-analysis. JAMA, 298(2): 194-206.

Bergenstal, R., Lewin, A., Bailey, T., Chang, D., Gylvin, T. \& Roberts, V. (2009). Efficacy and safety of biphasic insulin aspart $70 / 30$ versus exenatide in subjects with type 2 diabetes failing to achieve glycemic control with metformin and a sulfonylurea. Current Medical Research and Opinion, 25(1): 65-75.

Bjorkhem-Bergman, L., Asplund, A. B. \& Lindh, J. D. (2010). Metformin for weight reduction in non-diabetic patients on antipsychotic drugs: a systematic review and meta-analysis. Journal of Psychopharmacology.

Buse, J. B., Henry, R. R., Han, J., Kim, D. D., Fineman, M. S. \& Baron, A. D. (2004). Effects of exenatide (exendin-4) on glycemic control over 30 weeks in sulfonylurea-treated patients with type 2 diabetes. Diabetes Care, 27(11): 2628-2635.

Davis, S. N., Johns, D., Maggs, D., Xu, H., Northrup, J. H. \& Brodows, R. G. (2007). Exploring the substitution of exenatide for insulin in patients with type 2 diabetes treated with insulin in combination with oral antidiabetes agents. Diabetes Care, 30(11): 2767-2772.

Defronzo, R. A., Ratner, R. E., Han, J., Kim, D. D., Fineman, M. S. \& Baron, A. D. (2005). Effects of exenatide (exendin-4) on glycemic control and weight over 30 weeks in metformin-treated patients with type 2 diabetes. Diabetes Care, 28(5): 1092-1100.

Feldstein, A. C., Nichols, G. A., Smith, D. H., Stevens, V. J., Bachman, K., Rosales, A. G. \& Perrin, N. (2008). Weight change in diabetes and glycemic and blood pressure control. Diabetes Care, 31(10): 1960-1965.

Gao, Y., Yoon, K. H., Chuang, L. M., Mohan, V., Ning, G., Shah, S., Jang, H. C., Wu, T. J., Johns, D., Northrup, J. \& Brodows, R. (2009). Efficacy and safety of exenatide in patients of Asian descent with type 2 diabetes inadequately controlled with metformin or metformin and a sulphonylurea. Diabetes Research and Clinical Practice, 83(1): 69-76.

Heine, R. J., Van Gaal, L. F., Johns, D., Mihm, M. J., Widel, M. H. \& Brodows, R. G. (2005). Exenatide versus insulin glargine in patients with suboptimally controlled type 2 diabetes: a randomized trial. Annals of Internal Medicine, 143(8): 559-569.

Higgins, J. P., Thompson, S. G., Deeks, J. J. \& Altman, D. G. (2003). Measuring inconsistency in meta-analyses. BMJ, 327(7414): 557-560.

Kendall, D. M., Riddle, M. C., Rosenstock, J., Zhuang, D., Kim, D. D., Fineman, M. S. \& Baron, A. D. (2005). Effects of exenatide (exendin-4) on glycemic control over 30 weeks in patients with type 2 diabetes treated with metformin and a sulfonylurea. Diabetes Care, 28(5): 1083-1091

Kim, D., MacConell, L., Zhuang, D., Kothare, P. A., Trautmann, M., Fineman, M. \& Taylor, K. (2007). Effects of once-weekly dosing of a long-acting release formulation of exenatide on glucose control and body weight in subjects with type 2 diabetes. Diabetes Care, 30(6): 1487-1493.

Moretto, T. J., Milton, D. R., Ridge, T. D., Macconell, L. A., Okerson, T., Wolka, A. M. \& Brodows, R. G. (2008). Efficacy and tolerability of exenatide monotherapy over 24 weeks in antidiabetic drug-naive patients with type 2 diabetes: a randomized, double-blind, placebo-controlled, parallel-group study. Clinical Therapeutics, 30(8): 1448-1460.

Nathan, D. M., Buse, J. B., Davidson, M. B., Ferrannini, E., Holman, R. R., Sherwin, R. \& Zinman, B. (2009a). Medical management of hyperglycaemia in type 2 diabetes mellitus: a consensus algorithm for the initiation and adjustment of therapy. Diabetologia, 52(1): 17-30.

Nathan, D. M., Buse, J. B., Davidson, M. B., Ferrannini, E., Holman, R. R., Sherwin, R. \& Zinman, B. (2009b). Medical management of hyperglycemia in type 2 diabetes: a consensus algorithm for the initiation and adjustment of therapy: a consensus statement of the American Diabetes Association and the European Association for the Study of Diabetes. Diabetes Care, 32(1): 193-203.

Nauck, M. A., Duran, S., Kim, D., Johns, D., Northrup, J., Festa, A., Brodows, R. \& Trautmann, M. (2007). A comparison of twice-daily exenatide and biphasic insulin aspart in patients with type 2 diabetes who were suboptimally controlled with sulfonylurea and metformin: a non-inferiority study. Diabetologia, 50(2): 259-267. 
International Journal of Management, Economics and Social Sciences

Norris, S. L., Lee, N., Thakurta, S. \& Chan, B. K. (2009). Exenatide efficacy and safety: a systematic review. Diabetic Medicine, 26(9): 837-846.

Seagle, H. M., Strain, G. W., Makris, A. \& Reeves, R. S. (2009). Position of the American Dietetic Association: weight management. Journal of the American Dietetic Association, 109(2): 330-346.

Swinnen, S. G., Dain, M. P., Aronson, R., Davies, M., Gerstein, H. C., Pfeiffer, A. F., Snoek, F. J., Devries, J. H., Hoekstra, J. B. \& Holleman, F. (2010). A 24-week, randomized, treat-to-target trial comparing initiation of insulin glargine once-daily with insulin detemir twice-daily in patients with type 2 diabetes inadequately controlled on oral glucose-lowering drugs. Diabetes Care.

U.S. Food and Drug Administration, F. (2007). MedWatch The FDA Safety Information and Adverse Event Reporting Program: Byetta (exenatide) - FDA warning. Retrieved June 28, 2010, from http://www.fda.gov/Safety/MedWatch/Safety Information / SafetyAlertsforHumanMedicalProducts/ucm 150839.htm

U.S. Food and Drug Administration, F. (2009). MedWatch The FDA Safety Information and Adverse Event Reporting Program: Byetta (exenatide) - Renal Failure. Retrieved June 28, 2010, from http://www.fda.gov/Safety/MedWatch/ Safety Information /SafetyAlertsforHumanMedicalProducts/ucm 188703.htm

UK Prospective Diabetes Study Group, U. (1998). Intensive blood-glucose control with sulphonylureas or insulin compared with conventional treatment and risk of complications in patients with type 2 diabetes (UKPDS 33). Lancet, 352(9131): $837-853$.

Verspohl, E. J. (2009). Novel therapeutics for type 2 diabetes: incretin hormone mimetics (glucagon-like peptide-1 receptor agonists) and dipeptidyl peptidase-4 inhibitors. Pharmacology \& Therapeutics, 124(1): 113-138.

Weise, W. J., Sivanandy, M. S., Block, C. A. \& Comi, R. J. (2009). Exenatide-associated ischemic renal failure. Diabetes Care, 32(2): e22-23.

Wild, S., Roglic, G., Green, A., Sicree, R. \& King, H. (2004). Global prevalence of diabetes: estimates for the year 2000 and projections for 2030. Diabetes Care, 27(5): 1047-1053.

Zinman, B., Hoogwerf, B. J., Duran Garcia, S., Milton, D. R., Giaconia, J. M., Kim, D. D., Trautmann, M. E. \& Brodows, R. G. (2007). The effect of adding exenatide to a thiazolidinedione in suboptimally controlled type 2 diabetes: a randomized trial. Annals of Internal Medicine, 146(7): 477-485.

\section{ACKNOWLEDGEMENT}

This study was supported by grants from the National Defense Medical Center (DOD 97-T11-05 and DOD98-14-08-021), Taipei, Taiwan. 


\begin{tabular}{|c|c|c|c|c|c|c|c|}
\hline Study & $\begin{array}{l}\text { Patient } \\
\text { s, n/ } \\
\text { Durati } \\
\text { on, wk }\end{array}$ & $\begin{array}{c}\text { Mean } \\
\text { age, y/ } \\
\text { Women, } \\
\text { \%/ } \\
\text { White, } \\
\%\end{array}$ & $\begin{array}{c}\text { BMI, } \\
\text { kg/cm } / \\
\text { Diabetes } \\
\text { Duration, } \\
\text { y/ } \\
\text { HbA1c, } \\
\% \\
\end{array}$ & Exenatide therapy groups & Control groups & $\begin{array}{l}\text { Study } \\
\text { design }\end{array}$ & $\begin{array}{l}\text { Drop } \\
\text { out } \\
\text { rate, } \\
\%\end{array}$ \\
\hline $\begin{array}{l}\text { Buse } \\
2004\end{array}$ & $377 / 30$ & $55 / 40 / 63$ & $33 / 6.6 / 8.6$ & $\begin{array}{c}\text { SU }+5 \mu \mathrm{g} \text { BID exenatide } \\
\text { SU }+10 \mu \mathrm{g} \text { BID exenatide }\end{array}$ & $\mathrm{SU}+$ placebo & $\begin{array}{l}\mathrm{R}, \mathrm{MC} \\
\mathrm{ITT}, \mathrm{TB}, \\
\quad \mathrm{PC}\end{array}$ & 31 \\
\hline $\begin{array}{l}\text { DeFro } \\
\text { nzo } \\
2005\end{array}$ & $336 / 30$ & $53 / 43 / 76$ & $34 / 5.9 / 8.2$ & $\begin{array}{c}\text { MET }+5 \mu \mathrm{g} \text { BID exenatide } \\
\mathrm{MET}+10 \mu \mathrm{g} \text { BID } \\
\text { exenatide }\end{array}$ & $\mathrm{MET}+$ placebo & $\begin{array}{l}\mathrm{R}, \mathrm{MC} \\
\mathrm{ITT}, \mathrm{TB} \\
\quad \mathrm{PC}\end{array}$ & 19 \\
\hline $\begin{array}{l}\text { Kenda } \\
112005\end{array}$ & $733 / 30$ & $55 / 42 / 68$ & $34 / 8.9 / 8.5$ & $\begin{array}{c}\text { MET and/or SU }+5 \mu \mathrm{g} \\
\text { BID exenatide } \\
\text { MET and/or SU }+10 \mu \mathrm{g} \\
\text { BID exenatide }\end{array}$ & $\begin{array}{l}\text { MET and/or SU + } \\
\text { placebo }\end{array}$ & $\begin{array}{l}\mathrm{R}, \mathrm{MC} \\
\mathrm{ITT}, \mathrm{DB} \\
\quad \mathrm{PC}\end{array}$ & 19 \\
\hline $\begin{array}{l}\text { Morett } \\
\text { o } \\
2008\end{array}$ & $232 / 24$ & $54 / 45 / 68$ & $31 / 2 / 7.8$ & $\begin{array}{c}5 \mu \mathrm{g} \text { BID exenatide } \\
10 \mu \mathrm{g} \text { BID exenatide }\end{array}$ & placebo & $\begin{array}{l}\mathrm{R}, \mathrm{MC} \\
\mathrm{ITT}, \mathrm{OL} \\
\quad \mathrm{PC}\end{array}$ & 13 \\
\hline $\begin{array}{l}\text { Zinma } \\
\text { n } 2007\end{array}$ & $233 / 16$ & $56 / 45 / 82$ & $34 / 8.2 / 7.9$ & $\begin{array}{c}\text { TZD and/or MET }+10 \mu \mathrm{g} \\
\text { BID exenatide }\end{array}$ & $\begin{array}{l}\text { TZD and/or MET } \\
+ \text { placebo }\end{array}$ & $\begin{array}{l}\mathrm{R}, \mathrm{MC} \\
\mathrm{DB}, \mathrm{PC}\end{array}$ & 22 \\
\hline $\begin{array}{c}\text { Gao } \\
2009\end{array}$ & $466 / 16$ & $\begin{array}{l}54 / 56 / \text { As } \\
\text { ian }\end{array}$ & $26 / 8 / 8.3$ & $\begin{array}{c}\text { MET and/or SU }+10 \mu \mathrm{g} \\
\text { BID exenatide }\end{array}$ & $\begin{array}{l}\text { MET and/or SU + } \\
\text { placebo }\end{array}$ & $\begin{array}{l}\mathrm{R}, \mathrm{MC} \\
\mathrm{DB}, \mathrm{PC}\end{array}$ & 14 \\
\hline $\begin{array}{l}\text { Kim } \\
2007\end{array}$ & $45 / 15$ & $54 / 40 / 60$ & $36 / 5 / 8.5$ & $\begin{array}{c}\text { MET }+0.8 \text { mg LAR } \\
\text { exenatide } \\
\text { MET }+2.0 \mathrm{mg} \\
\text { LARexenatide }\end{array}$ & $\mathrm{MET}+$ placebo & $\begin{array}{l}\mathrm{R}, \mathrm{MC} \\
\mathrm{ITT}, \mathrm{DB} \\
\quad \mathrm{PC}\end{array}$ & 4 \\
\hline $\begin{array}{l}\text { Heine } \\
2005\end{array}$ & $551 / 26$ & $58 / 44 / 80$ & $31 / 9.6 / 8.2$ & $\begin{array}{c}\text { MET and SU }+10 \mu \mathrm{g} \text { BID } \\
\text { exenatide }\end{array}$ & $\begin{array}{l}\text { MET and SU + } \\
\text { insulin glargine }\end{array}$ & $\begin{array}{l}\mathrm{R}, \mathrm{MC} \\
\mathrm{ITT}, \mathrm{OL}\end{array}$ & 15 \\
\hline $\begin{array}{l}\text { Berge } \\
\text { nstal } \\
2009\end{array}$ & $372 / 24$ & $53 / 52 / 64$ & $34 / 9 / 10.2$ & $\begin{array}{c}\text { MET and SU }+10 \mu \mathrm{g} \text { BID } \\
\text { exenatide }\end{array}$ & $\begin{array}{l}\text { MET and SU + } \\
\text { BIAsp } 30 \text { BID } \\
\text { MET + BIAsp } 30 \\
\text { QD }\end{array}$ & $\begin{array}{l}\mathrm{R}, \mathrm{MC} \\
\mathrm{OL}\end{array}$ & 22 \\
\hline $\begin{array}{l}\text { Nauck } \\
2007\end{array}$ & $501 / 52$ & $\begin{array}{c}59 / 49 / \mathrm{N} \\
\mathrm{A}\end{array}$ & $30 / 10 / 8.6$ & $\begin{array}{c}\text { MET and SU }+10 \mu \mathrm{g} \text { BID } \\
\text { exenatide }\end{array}$ & $\begin{array}{l}\text { MET and SU + } \\
\text { BIAsp } 30 \text { BID }\end{array}$ & $\begin{array}{l}\mathrm{R}, \mathrm{MC} \\
\mathrm{ITT}, \mathrm{OL}\end{array}$ & 11 \\
\hline $\begin{array}{l}\text { Davis } \\
2007\end{array}$ & $49 / 16$ & $\begin{array}{c}53 / 53 / \mathrm{N} \\
\mathrm{A}\end{array}$ & $34 / 11 / 8.1$ & $\begin{array}{c}\text { MET and SU }+10 \mu \mathrm{g} \text { BID } \\
\text { exenatide }\end{array}$ & $\begin{array}{l}\text { MET and SU + } \\
\text { insulin }\end{array}$ & $\begin{array}{l}\mathrm{R}, \mathrm{MC} \\
\mathrm{OL}\end{array}$ & 0 \\
\hline
\end{tabular}

Table 1. Characteristic of Randomized Controlled Trials of Exenatide included in the Systematic Review 
International Journal of Management, Economics and Social Sciences

Appendix-II

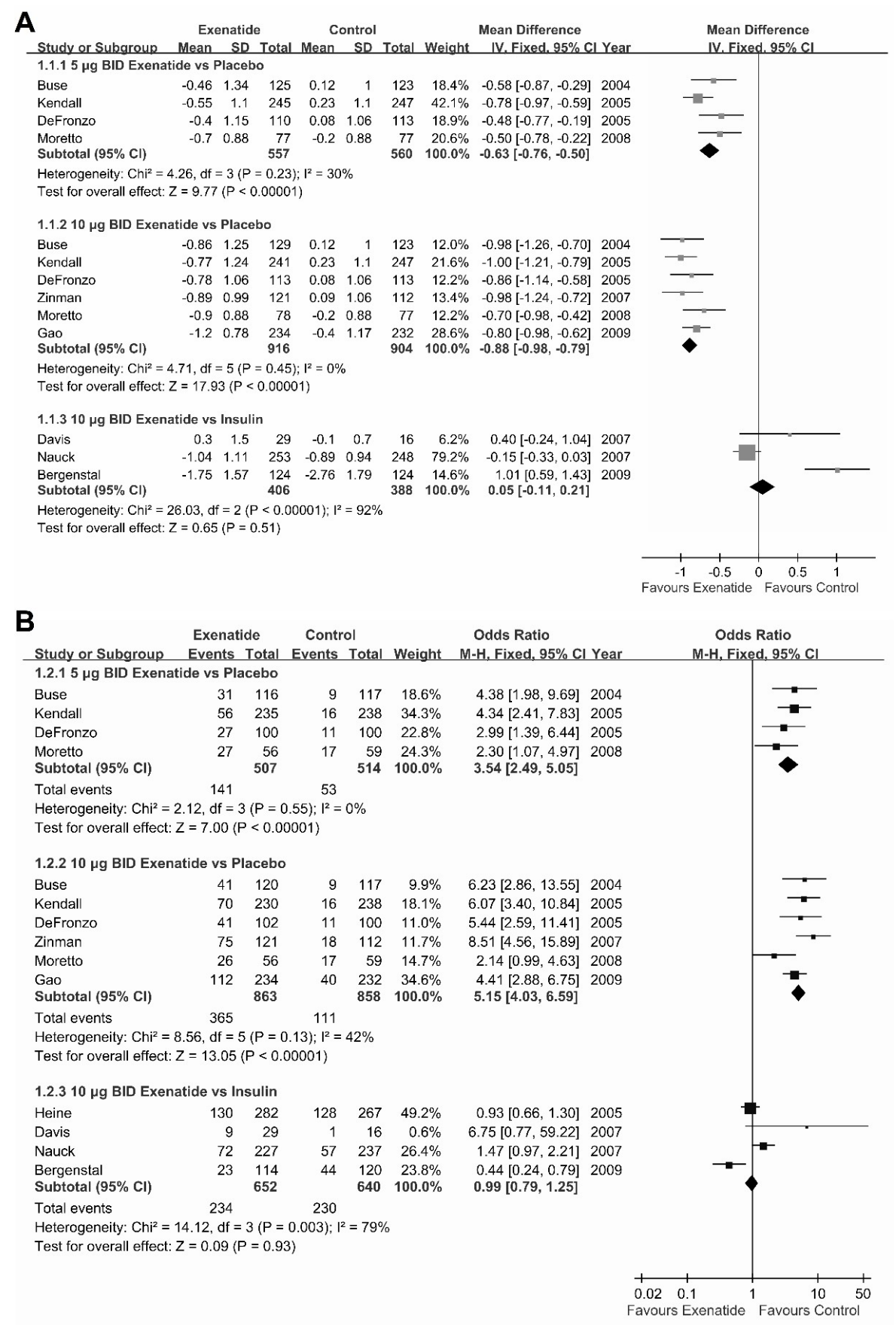

Source: Developed for this study

Figure 2. HbAlc Changes for Exenatide vs. Control in Patients with Type 2 Diabetes. (A) Mean difference in HbAlc (\%) (B) Odds ratio for reaching target HbAlc concentration of less than 7\%. The forest plot presents the meta-analysis data pooled by the fixed effect Mantel-Haenszel (M-H) method.

The I2 value describes the percentage of total variation across the studies due to heterogeneity 
Appendix-III

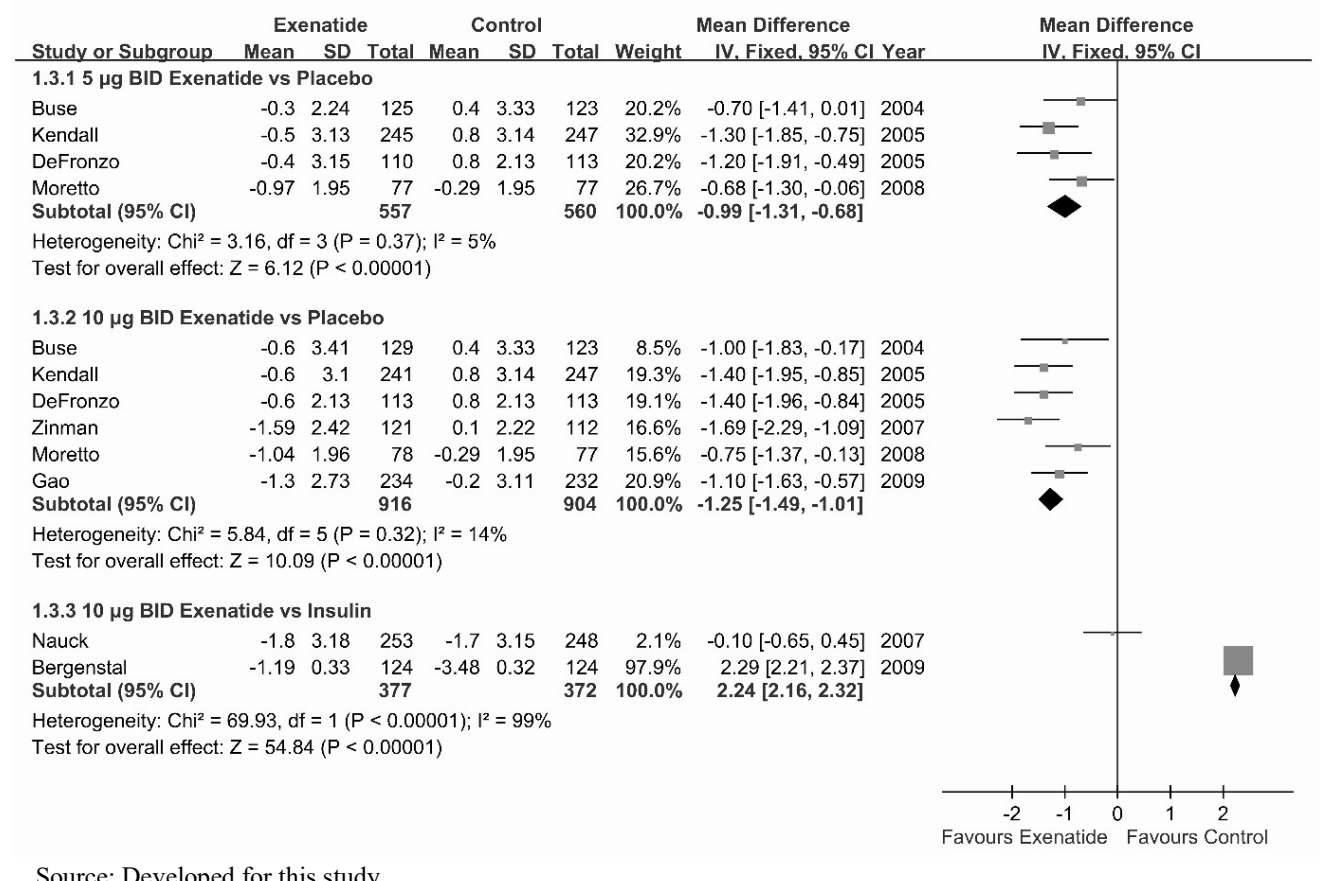

Figure 3. Mean Differences in Body Weight (kg) Changes for Exenatide vs. Control in Patients with

Type 2 Diabetes. The forest plot presents the meta-analysis data pooled by the fixed effect Mantel-

Haenszel (M-H) method. The I2 value describes the percentage of total variation across the studies due to heterogeneity. 


\begin{tabular}{|c|c|c|c|c|c|c|c|c|c|c|c|}
\hline \multirow[b]{2}{*}{ Study or Subgroup } & \multicolumn{3}{|c|}{ Exenatide } & \multicolumn{3}{|c|}{ Control } & \multicolumn{3}{|c|}{ Mean Difference } & \multirow{2}{*}{\multicolumn{2}{|c|}{$\begin{array}{l}\text { Mean Difference } \\
\text { IV. Fixed, } 95 \% \mathrm{Cl}\end{array}$}} \\
\hline & Mean & SD & Total & Mean & SD & Total & Weight & IV. Fixed, $95 \% \mathrm{Cl}$ & Year & & \\
\hline \multicolumn{12}{|c|}{ 1.4.1 $5 \mu \mathrm{g}$ BID Exenatide vs Placebo } \\
\hline Buse & -0.9 & 3.35 & 125 & -0.6 & 3.33 & 123 & $20.1 \%$ & $-0.30[-1.13,0.53]$ & 2004 & & \\
\hline Kendall & -1.6 & 3.13 & 245 & -0.9 & 3.14 & 247 & $45.3 \%$ & $-0.70[-1.25,-0.15]$ & 2005 & 늠 & \\
\hline DeFronzo & -1.6 & 4.2 & 110 & -0.3 & 3.19 & 113 & $14.5 \%$ & $-1.30[-2.28,-0.32]$ & 2005 & 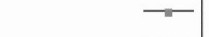 & \\
\hline $\begin{array}{l}\text { Moretto } \\
\text { Subtotal }(95 \% \mathrm{Cl})\end{array}$ & -2.8 & 2.63 & $\begin{array}{r}77 \\
557\end{array}$ & -1.4 & 2.63 & $\begin{array}{r}77 \\
560\end{array}$ & $\begin{array}{r}20.1 \% \\
100.0 \%\end{array}$ & $\begin{array}{l}-1.40[-2.23,-0.57] \\
-0.85[-1.22,-0.47]\end{array}$ & 2008 & - & \\
\hline \multicolumn{12}{|c|}{$\begin{array}{l}\text { Heterogeneity: } \mathrm{Chi}^{2}=4.45, \mathrm{df}=3(\mathrm{P}=0.22) ;\left.\right|^{2}=33 \% \\
\text { Test for overall effect: } Z=4.45(P<0.00001)\end{array}$} \\
\hline \multicolumn{12}{|c|}{ 1.4.2 $10 \mu \mathrm{g}$ BID Exenatide vs Placebo } \\
\hline Buse & -1.6 & 3.41 & 129 & -0.6 & 3.33 & 123 & $9.3 \%$ & $-1.00[-1.83,-0.17]$ & 2004 & & \\
\hline DeFronzo & -2.8 & 5.32 & 113 & -0.3 & 3.19 & 113 & $4.9 \%$ & $-2.50[-3.64,-1.36]$ & 2005 & & \\
\hline Kendall & -1.6 & 3.1 & 241 & -0.9 & 3.14 & 247 & $21.1 \%$ & $-0.70[-1.25,-0.15]$ & 2005 & -- & \\
\hline Zinman & -1.75 & 2.75 & 121 & -0.24 & 2.75 & 112 & $12.9 \%$ & $-1.51[-2.22,-0.80]$ & 2007 & - & \\
\hline Moretto & -3.1 & 2.65 & 78 & -1.4 & 2.63 & 77 & $9.3 \%$ & $-1.70[-2.53,-0.87]$ & 2008 & - & \\
\hline $\begin{array}{l}\text { Gao } \\
\text { Subtotal }(95 \% \mathrm{Cl})\end{array}$ & -1.2 & 2.33 & $\begin{array}{l}234 \\
916\end{array}$ & -0.1 & 1.95 & $\begin{array}{l}232 \\
904\end{array}$ & $\begin{array}{r}42.4 \% \\
100.0 \%\end{array}$ & $\begin{array}{l}-1.10[-1.49,-0.71] \\
-1.18[-1.44,-0.93]\end{array}$ & 2009 & 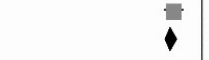 & \\
\hline \multicolumn{12}{|c|}{$\begin{array}{l}\text { Heterogeneity: } \mathrm{Chi}^{2}=10.69, \mathrm{df}=5(\mathrm{P}=0.06) ; \mathrm{I}^{2}=53 \% \\
\text { Test for overall effect: } Z=9.14(P<0.00001)\end{array}$} \\
\hline \multicolumn{12}{|c|}{ 1.4.3 $10 \mu \mathrm{g}$ BID Exenatide vs Insulin } \\
\hline Nauck & -2.5 & 3.18 & 253 & 2.9 & 3.15 & 248 & $71.9 \%$ & $-5.40[-5.95,-4.85]$ & 2007 & & \\
\hline Davis & -4.2 & 3 & 29 & 0.5 & 1.7 & 16 & $11.7 \%$ & $-4.70[-6.07,-3.33]$ & 2007 & & \\
\hline $\begin{array}{l}\text { Bergenstal } \\
\text { Subtotal }(95 \% \mathrm{CI})\end{array}$ & -1.9 & 3.8 & $\begin{array}{l}124 \\
406\end{array}$ & 4.1 & 5.4 & $\begin{array}{l}124 \\
388\end{array}$ & $\begin{array}{r}16.4 \% \\
100.0 \%\end{array}$ & $\begin{array}{l}-6.00[-7.16,-4.84] \\
-5.42[-5.89,-4.95]\end{array}$ & 2009 & & \\
\hline \multicolumn{12}{|c|}{$\begin{array}{l}\text { Heterogeneity: } \mathrm{Chi}^{2}=2.02, \mathrm{df}=2(\mathrm{P}=0.36) ; \mathrm{I}^{2}=1 \% \\
\text { Test for overall effect: } Z=22.58(P<0.00001)\end{array}$} \\
\hline & & & & & & & & & & Favours Exenatide & 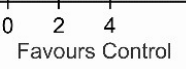 \\
\hline
\end{tabular}

Figure 4. Mean Differences in FPG (mmole/L) Changes for Exenatide vs. Control in Patients with Type 2 Diabetes. The forest plot presents the meta-analysis data pooled by the fixed effect Mantel-Haenszel (M-H) method. The I2 value describes the percentage of total variation across the studies due to heterogeneity 


\begin{tabular}{|c|c|c|c|c|c|}
\hline Adverse Events & $\begin{array}{l}\text { Studies } \\
\text { (n) }\end{array}$ & $\begin{array}{c}\text { Odds ratio } \\
\text { (M-H, Fixed, 95\% CI) }\end{array}$ & $\begin{array}{r}\text { Exenatide } \\
\text { Participa } \\
\end{array}$ & $\begin{array}{l}\text { Control } \\
\text { tts }(n)\end{array}$ & $\begin{array}{c}I^{2} \\
(\%) *\end{array}$ \\
\hline \multicolumn{6}{|l|}{ Hypoglycemia } \\
\hline $5 \mu \mathrm{g}$ BID exenatide vs placebo & 4 & $1.92[1.28,2.88]$ & 557 & 560 & 44 \\
\hline $10 \mu \mathrm{g}$ BID exenatide vs placebo & 5 & $3.17[2.24,4.48]$ & 682 & 672 & 75 \\
\hline $10 \mu \mathrm{g}$ BID exenatide vs insulin & 1 & $0.63[0.41,0.97]$ & 253 & 248 & NA \\
\hline \multicolumn{6}{|l|}{ Nausea } \\
\hline $5 \mu \mathrm{g}$ BID exenatide vs placebo & 4 & $2.92[2.17,3.92]$ & 557 & 560 & 69 \\
\hline $10 \mu \mathrm{g}$ BID Exenatide vs placebo & 6 & $5.25[4.07,6.77]$ & 916 & 904 & 79 \\
\hline $10 \mu \mathrm{g}$ BID Exenatide vs insulin & 2 & $20.89[13.04,33.49]$ & 535 & 515 & 86 \\
\hline \multicolumn{6}{|l|}{ Vomiting } \\
\hline $5 \mu \mathrm{g}$ BID exenatide vs placebo & 4 & $3.82[2.24,6.51]$ & 557 & 560 & 0 \\
\hline $10 \mu \mathrm{g}$ BID Exenatide vs placebo & 6 & $6.71[4.13,10.89]$ & 916 & 904 & 43 \\
\hline $10 \mu \mathrm{g}$ BID Exenatide vs insulin & 2 & $5.36[3.18,9.04]$ & 535 & 515 & 0 \\
\hline \multicolumn{6}{|l|}{ Diarrhea } \\
\hline $5 \mu \mathrm{g}$ BID exenatide vs placebo & 3 & $1.84[1.15,2.94]$ & 557 & 560 & 0 \\
\hline $10 \mu \mathrm{g}$ BID exenatide vs placebo & 6 & $2.91[1.93,4.40]$ & 916 & 904 & 0 \\
\hline $10 \mu \mathrm{g}$ BID exenatide vs insulin & 2 & $3.80[2.03,7.10]$ & 535 & 515 & 0 \\
\hline \multicolumn{6}{|l|}{ Headache } \\
\hline $5 \mu \mathrm{g}$ BID exenatide vs placebo & 3 & $1.91[1.13,3.24]$ & 447 & 447 & 0 \\
\hline $10 \mu \mathrm{g}$ BID exenatide vs placebo & 5 & $1.24[0.77,1.98]$ & 803 & 791 & 0 \\
\hline $10 \mu \mathrm{g}$ BID exenatide vs insulin & 2 & $0.98[0.61,1.58]$ & 535 & 515 & 0 \\
\hline \multicolumn{6}{|l|}{ Dizziness } \\
\hline $5 \mu \mathrm{g}$ BID exenatide vs placebo & 2 & $2.07[1.08,3.97]$ & 312 & 313 & 0 \\
\hline $10 \mu \mathrm{g}$ BID exenatide vs placebo & 4 & $2.13[1.22,3.72]$ & 554 & 545 & 36 \\
\hline $10 \mu \mathrm{g}$ BID exenatide vs insulin & 1 & $2.44[0.93,6.40]$ & 282 & 267 & NA \\
\hline \multicolumn{6}{|l|}{ Feeling Jittery } \\
\hline $5 \mu \mathrm{g}$ BID exenatide vs placebo & 2 & $1.99[1.12,3.53]$ & 370 & 370 & 81 \\
\hline $10 \mu \mathrm{g}$ BID exenatide vs placebo & 2 & $2.69[1.55,4.69]$ & 370 & 370 & 80 \\
\hline
\end{tabular}

Table 2. Summary of Adverse Events in Patients with Type 2 Diabetes Treated with Exenatide vs. 